\title{
The use of gadolinium and europium concentrations as contaminant tracers in the Nida River watershed in south-central Poland
}

\author{
Zdzisław M. MIGASZEWSKI ${ }^{1, *}$ and Agnieszka GAŁUSZKA ${ }^{1}$ \\ 1 Jan Kochanowski University, Faculty of Mathematics and Natural Sciences, Świętokrzyska 15G, 25-406 Kielce, Poland
}

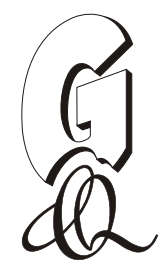

Migaszewski, Z.M., Gałuszka, A., 2016. The use of gadolinium and europium concentrations as contaminant tracers in the Nida River watershed in south-central Poland. Geological Quarterly, 60 (1): 67-76, doi: 10.7306/gq.1241

\begin{abstract}
This paper presents the results of rare earth element (REE) determinations in the Nowiny wastewater treatment plant (NWWTP) effluents and Nida River system waters of the southeastern Kielce Region (south-central Poland). Of the REE examined, gadolinium and europium turned out to be very useful for pinpointing anthropogenic and geogenic sources. Anthropogenic gadolinium $\left(\mathrm{Gd}_{\mathrm{anth}}\right)$, used as a contrasting agent in magnetic resonance imaging (MRI), is released from the NWWTP into the river drainage system. This micropollutant is traced downstream over the distance of about $15 \mathrm{~km}$. This river stretch is characterized by a strong positive NASC-normalized $\mathrm{Gd}_{\text {anth }}$ anomaly with the $\mathrm{Gd}_{\text {NASC }} / \mathrm{Gd}_{\text {NASC }}{ }^{*}$ ratio above 1.1 $(1.80-15.57)$ and the $\mathrm{Gd}_{a n t h}$ input varying from 44 to $94 \%$. Two additional positive $\mathrm{Gd}_{\text {anth }}$ anomalies recorded in the rivers Bobrza and Nida point out to mixing of effluents derived from the NWWTP and other local wastewater treatment plants. In

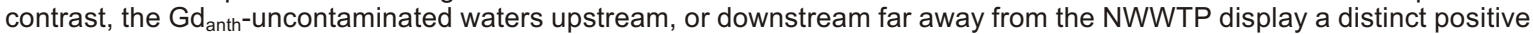
NASC-normalized Eu anomaly highlighted by a high Eu/Eu* ratio in the range of 2.87 to 29.70 . The lack of $\mathrm{Gd}_{\text {anth }}$ anomaly upstream from the NWWTP also indicates that there is no leakage of municipal sewage from the sanitary collector sewer into the Silnica River. Thus Gd as a contaminant may be effectively used as a tracer in similar pollution studies because it is relatively simple and cost-effective to discriminate between contaminant concentrations and normal background concentrations.
\end{abstract}

Key words: rare earth elements, wastewater effluent, Nida River drainage system, anthropogenic gadolinium, geogenic europium.

\section{INTRODUCTION}

Europium (Eu) and gadolinium (Gd) belong to the lanthanides (lanthanoids) with atomic number 57 (La) through $71(\mathrm{Lu})$. Eu is usually rated among the light rare earth elements (LREE) from La through $\mathrm{Eu}$, whereas $\mathrm{Gd}$ among the heavy rare earth elements (HREE) from Gd through $L u$. In another classification of REE, Eu and $\mathrm{Gd}$ are also assigned to the medium REE (MREE) group that comprises Sm through Ho. In contrast to $\mathrm{Eu}\left(\mathrm{Eu}^{2+}, \mathrm{Eu}^{3+}\right), \mathrm{Gd}$ occurs only in a trivalent state in nature (Migaszewski and Gałuszka, 2015).

Of these two elements, gadolinium has found wide applications in magnetic resonance imaging (MRI) as a contrasting reagent due to a high magnetic moment of the paramagnetic $\mathrm{Gd}^{3+}$ ion (e.g., Kümmerer and Helmers, 2000; Möller et al., 2003; Möller and Dulski, 2010). Because $\mathrm{Gd}^{3+}$ is toxic to the human organism, therefore, this element must be administered to patients in the form of non-reactive and stable chemical complex species. Kümmerer and Helmers (2000) reported that the level of $\mathrm{Gd}$ in urine may reach $350 \mathrm{mg} / \mathrm{L}$ daily after the patient exam

\footnotetext{
* Corresponding author, e-mail: zmig@ujk.edu.pl
}

Received: March 9, 2015; accepted: July 8, 2015; first published online: July 9, 2015 and $7 \mu \mathrm{g} / \mathrm{L}$ after 39 days. The stable $\mathrm{Gd}$ chelates may be released with antibiotics, antihypertensives, antiinflammatories, antihistamines and estrogens from medical facilities to municipal sewage systems (Verplanck et al., 2003; Barber et al., 2003; Morteani et al., 2006). This is the reason why strong positive $\mathrm{Gd}$ anomalies in the REE pattern have been reported in river, underground, coastal and potable waters of densely populated and industrialized areas with a developed medical system (e.g., Bau and Dulski, 1996; Nozaki et al., 2000; Möller et al., 2000, 2002; Elbaz-Poulichet et al., 2002; Verplanck et al., 2005; Zhu et al., 2005; Bau et al., 2006; Lawrence et al., 2006, 2009; Kulaksız and Bau, 2007, 2013; Rabiet et al., 2009; Lawrence, 2010; Lawrence and Bariel, 2010).

Free $\mathrm{Gd}^{3+}$ ion competes with $\mathrm{Ca}^{2+}$ in the human body. The $\mathrm{Gd}^{3+}$ ions can be released through dechelation of less stable $\mathrm{Gd}$ chelates. This may bring about nephrogenic systemic fibrosis in patients with kidney failure or insufficiency (Idée et al., 2008) and disturbance of calcium homeostasis in the organism (Kulaksız and Bau, 2011).

This paper summarizes the results of $\mathrm{Gd}$ and Eu vs. other REE determinations in the Nida watershed system of the southern part of the Kielce Region, south-central Poland. The principal objectives of this pilot study were: (1) to discriminate anthropogenic $\mathrm{Gd}$ from its geogenic equivalent in the river system examined, (2) to compare anthropogenic $\mathrm{Gd}$ and geogenic Eu anomalies, (3) to determine the effluent range of the Nowiny wastewater treatment plant (NWWTP), and (4) to trace any unauthorized industrial wastewater discharges or a possible leak- 
age from the municipal sewage underground channel within the city limits of Kielce.

The studies of the anthropogenic gadolinium have widely been applied in Germany, the USA, Australia etc. However, these investigations have not been conducted in Poland so far. The results derived from the present study in the Nida watershed encourage to the widespread use of gadolinium anomaly for tracing anthropogenic pollution sources, especially in large urban-industrialized areas with advanced healthcare system.

\section{MATERIALS AND METHODS}

\section{STUDY AREA}

The study area is located in the southwestern part of the Paleozoic Holy Cross Mountains and in the central part of the Cretaceous Nida Trough. The drainage pattern consists of the Nida River that flows southeastward to the Vistula River across exposed Miocene limestone-sandstone-gypsum deposits. The tributary network includes (from the north to the south) the following rivers: Silnica, Bobrza and Czarna Nida (Fig. 1). They flow across different Paleozoic, Triassic and Jurassic carbonate, locally siliciclastic formations. The Silnica River flows through the city of Kielce (population of over 200,000) into the Bobrza River.

The Nowiny wastewater treatment plant (NWWTP) is located near the right-bank of the Bobrza River. The municipal underground sewage channel partly overlaps the Silnica-Bobrza River system. The annual air temperature of the study area averages $7.4^{\circ} \mathrm{C}$ with mean precipitation $600 \mathrm{~mm}$ and prevailing westerly and north-westerly winds (WIOŚ, 2000). There are a few medical MRI facilities in Kielce and the neighbouring area that use $\mathrm{Gd}$ chelates for diagnostic purposes.

\section{FIELDWORK AND SAMPLING}

Fieldwork was conducted on October 23 and November 27 of 2013 as well as on January 23 and April 8 of 2014. Sampling locations are reported in Figure 1. During the first field series 2 water samples (NWWTP1, B3a) were collected for pilot determinations of REE, $Y$ and selected trace elements. During the November series 10 water samples were taken. They encompassed: 7 samples (B4, B5, and S1 through S5) collected upstream from the NWWTP, 1 sample from the NWWTP wastewater (NWWTP2) and 2 samples from the Bobrza River downstream from the NWWTP (B3b, B2a). The principal objective of this study phase was to compare the shale-normalized REE patterns and trace element geochemistry upstream and downstream from the NWWTP. Fieldwork also included on-site measurements of $\mathrm{pH}$, electroconductivity (EC) and temperature (T). During the January, 2014 series only 2 water samples were collected (NWWTP3, B3c). The April, 2014 series encompassed sampling downstream from the NWWTP to the Vistula River. In all, 11 water samples were collected (NWWTP4, B3c, $\mathrm{B} 2 \mathrm{~b}, \mathrm{~B} 1, \mathrm{CN}, \mathrm{N} 1 \mathrm{through} \mathrm{N6}$ ). The main purpose of this study phase was to establish the extent of $\mathrm{Gd}$ anomaly. In addition, during the third and fourth sampling series on-site measurements were performed including $\mathrm{pH}, \mathrm{EC}$, redox potential (Eh), total dissolved solids (TDS), salinity and T using a $\mathrm{pH} / \mathrm{Eh}$-meter SP300 and an EC-meter SC300 equipped with temperature sensors (Slandi, Poland).

All the water samples for REE and other trace element determinations were filtered through $0.45 \mu \mathrm{m}$ pore-sized PTFE syringe filters and placed in $50 \mathrm{~mL}$ polypropylene vials. The water samples were transported on the day of sampling to the Geochemical Laboratory of the Institute of Chemistry, Jan Kochanowski University in Kielce and stored in a refrigerator at a temperature of about $4-6^{\circ} \mathrm{C}$. The chemical analysis was performed on the following day.

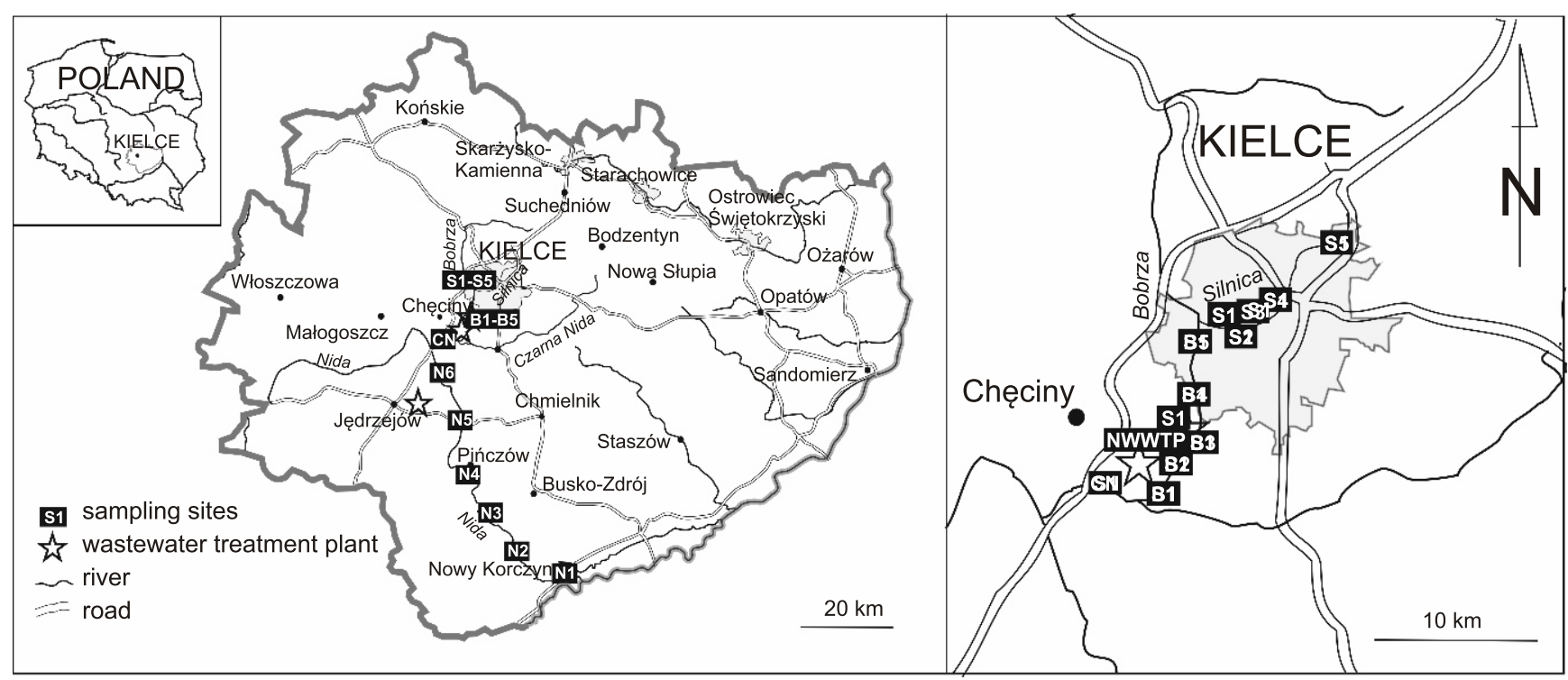

Fig. 1. Location of the study area with water sampling points.

Upstream sampling points: Silnica River (S1 through S5) and Bobrza River (B4, B5); NWWTP (Nowiny wastewater treatment plant) downstream sampling points: Bobrza River (B1 through B3), Czarna Nida River (CN) and Nida River (N1 through N6) 
MRI scans are only conducted on weekdays in medical facilities in Poland. Therefore, except for the April-series, the water samples were collected between Wednesday and Friday, based on the assumption that the residence time of anthropogenic $\mathrm{Gd}$ in the collecting system and NWWTP was about two days. This value was determined by Möller et al. (2003), and Lawrence and Bariel (2010). During sample collection, transport, storage and preparation, procedures were followed to minimize the possibility of contamination. A set of water samples included one blank (deionized water from the laboratory that was processed in the field along with the environmental samples) and one replicate sample for each sampling series.

\section{SAMPLE PREPARATION AND CHEMICAL ANALYSIS}

For the purpose of this study all the water samples were analysed for 14 REE (La through Lu), Y, Sc and 8 other trace elements (As, Cd, Co, Cr, Cu, Mn, Pb, Zn) using an ICP-MS instrument (model ELAN DRC II, Perkin Elmer). Instrumental and data acquisition parameters of the ICP-MS instrument were as follows: sweeps/reading -20 , readings/replicate -3 , replicates - 4, nebulizer gas flow - $1.03 \mathrm{~L} / \mathrm{min}$, plasma gas flow $15 \mathrm{~L} / \mathrm{min}$, lens voltage $-7.50 \mathrm{~V}$, plasma power $-1275 \mathrm{~W}$. The measurements were done in the peak hopping mode and the dwell time was 50-150 microseconds depending on the analyte. Two internal standards were utilized: Rh and Ir. Correction equations for $\mathrm{Nd}, \mathrm{Sm}, \mathrm{Gd}$, Dy, and $\mathrm{Yb}$ were used for elimination of REE-oxide interelement interferences. The ICP-MS instrument was optimized with a standard daily procedure. For REE determination a series of Multielement Calibration Standard 2 Perkin Elmer solutions and for trace element determination a series of Multielement Calibration Standard 3 Perkin Elmer solutions was employed.

The standard reference materials (SRM) applied for measuring element concentrations by ICP-MS were: NIST $1643 \mathrm{e}$ (trace elements in water) and the geologic multi-element reference material (GM-ERM) PPREE1 (Verplanck et al., 2001: table 2) for waters. For comparison, the REE concentrations derived from ICP-MS measurements were normalized to North American Shale Composite (NASC) using values given by Haskin et al. (1968) and Gromet et al. (1984). Quality control included both accuracy (CRM) and precision (triplicates). The average recovery of elements from the SRM and CRM was in the range of 83 to $116 \%$, whereas the uncertainty of the method $\left(U_{c}^{2}=u_{R M}{ }^{2}+u_{d}{ }^{2}+u_{m}{ }^{2}+B^{2}, U_{e}=2 \times U_{c}\right)^{*}$ was below $10 \%$. The RSD values were $<4 \%$ for most of the analysed samples.

\section{RESULTS AND DISCUSSION}

\section{GEOCHEMISTRY OF WATERS}

The $\mathrm{pH}, \mathrm{EC}$ and $\mathrm{T}$ values and concentrations of REE and selected trace metals in the waters of the middle reaches of the Bobrza River (B4, B5) and its left-bank tributary (Silnica River) upstream from the NWWTP are reported in Table 1. The pH and $\mathrm{EC}$ of these waters varied from 7.2 to 7.8 and from 374 to $687 \mu \mathrm{S} / \mathrm{cm}$, respectively. The higher $\mathrm{pH}$ and $\mathrm{EC}$ values were attributed to the Silnica River reflecting the bed lithology (mostly Upper Devonian limestones and marly-clayey shales). It should be mentioned that this river drainage area is highlighted by the occurrence of rock formations abundant with lead and iron ores that lead to higher natural concentration levels of these two elements in the surface waters (Rubinowski et al., 1966). The concentrations of selected trace elements were low being characteristic of bicarbonate waters. Somewhat higher levels of $\mathrm{Cd}$ $(0.18 \mu \mathrm{g} / \mathrm{L}), \mathrm{Co}(8.45 \mu \mathrm{g} / \mathrm{L}), \mathrm{Cu}(13.69 \mu \mathrm{g} / \mathrm{L})$ and $\mathrm{Mn}(1149$ $\mu \mathrm{g} / \mathrm{L})$ were noted at sampling point S5. The contents of total REE and $Y$ were also very low ranging from 0.128 to $0.327 \mu \mathrm{g} / \mathrm{L}$ and from 0.048 to 0.307 , respectively, with the highest levels also at sampling point S5. This may point to the geogenic origin of these elements because the upper reaches of the Silnica River (outside the city limits of Kielce) occur within Cambrian quartzites and clayey shales locally comprising pyrite and REE-bearing minerals (Migaszewski et al., 2007).

The NWWTP wastewaters had a somewhat lower $\mathrm{pH}$ of 6.9-7.0 and an EC value of 962-1196 $\mu \mathrm{S} / \mathrm{cm}$ (Table 2). Of the trace elements examined, only $\mathrm{Cr}(5.86-9.70 \mu \mathrm{g} / \mathrm{L})$ and $\mathrm{Zn}$ $(40-85 \mu \mathrm{g} / \mathrm{L})$ showed slightly higher levels compared to those upstream the Bobrza River (Tables 1 and 2). In contrast to $Y$ $(0.007-0.040 \mu \mathrm{g} / \mathrm{L})$, concentrations of total REE were the highest of all the sampling points $(0.464-0.590 \mu \mathrm{g} / \mathrm{L})$. However, Gd alone accounted for 55 to $87 \%$ of REE, i.e. $0.254-0.516 \mu \mathrm{g} / \mathrm{L}$ with a mean of $0.384 \mu \mathrm{g} / \mathrm{L}$ (Table 2). These Gd concentrations were similar to those $(0.032-0.505 \mu \mathrm{g} / \mathrm{L})$ noted in the effluents of seven wastewater treatment plants in Berlin (Knappe et al., 2005). In contrast, the effluents of the Wetalla WWTP, Queensland (Australia) exhibited lower Gd contents averaging $0.058 \mu \mathrm{g} / \mathrm{L}$ (Lawrence and Bariel, 2010).

The lower reaches of the Bobrza River (B3a-d, B2a, b, B1) showed high REE concentrations $(0.203-0.487 \mu \mathrm{g} / \mathrm{L})$, but especially $\mathrm{Gd}(0.036-0.160 \mu \mathrm{g} / \mathrm{L}$ (Tables 2 and 3). Compared to upstream sampling points (B4, B5) which exhibit low concentrations of $\mathrm{Gd}$, the waters of downstream sampling points B3, B2 and $\mathrm{B} 1$ are distinctly enriched in this element by a factor of 104 , 74 and 18, respectively. For comparison, the waters of lake Wärmeln (central Sweden) and the rivers Wupper and Havel, (Germany) contained 0.036, 0.019 and $0.159 \mu / \mathrm{L} \mathrm{Gd}$, respectively (Bau and Dulski, 1996). The other physicochemical parameters, i.e. $\mathrm{pH}(7.2-8.0)$ and $\mathrm{EC}(442-865 \mu \mathrm{S} / \mathrm{cm})$, as well as $Y$ and trace element contents do not differ much from those of the upper reaches of the Bobrza River upstream from the NWWTP.

The Nida River waters displayed similar values of $\mathrm{pH}$ (8.0-8.1) and other physicochemical parameters (EC, Eh, TDS, salinity, T) accompanied by the lowest concentrations of most trace elements, especially $\mathrm{Co}, \mathrm{Cu}, \mathrm{Mn}, \mathrm{Pb}, \mathrm{Zn}$ and $\mathrm{REE}$ (0.003-0.019 $\mu \mathrm{g} / \mathrm{L}$; Table 3). On April 8 of 2014 the contents of $\operatorname{REE}(0.185-0.295 \mu \mathrm{g} / \mathrm{L})$ and $Y(0.030-0.063 \mu \mathrm{g} / \mathrm{L})$ were nearly the same as those in the rivers Czarna Nida $(\mathrm{CN})$ and Bobrza (B3d, B2b, B1) downstream from the NWWTP (REE $0.203-0.258 \mu \mathrm{g} / \mathrm{L}$ and $\mathrm{Y} 0.040-0.054 \mu \mathrm{g} / \mathrm{L})$.

Similar REE mean concentrations (ca. $0.253 \mu \mathrm{g} / \mathrm{L}$ ) were found in about 500 circumneutral $\mathrm{pH}$ stream waters of Eastern Canada (Leybourne and Johannesson, 2008). For comparison, $\mathrm{Gd}$ and Eu concentrations were in the range of 0.001 to $0.026 \mu \mathrm{g} / \mathrm{L}$ (mean of $0.006 \mu \mathrm{g} / \mathrm{L}$ ) and 0.001 to $0.024 \mu \mathrm{g} / \mathrm{L}$ (excluding an outlier of $0.110 \mu \mathrm{g} / \mathrm{L}$ ), respectively. In the stream waters of Europe the contents of geogenic Gd varied from $<0.002$ to $0.87 \mu \mathrm{g} / \mathrm{L}$ with a mean of $0.045 \mathrm{mg} / \mathrm{L}$. Similarly, Eu concentrations were in the range of $<0.002-0.87 \mu \mathrm{g} / \mathrm{L}$ with a mean of $0.01 \mathrm{\mu g} / \mathrm{L}$ (Salminen et al., 2005; Petrosino et al., 2013). In south-central Poland the stream waters exhibited low levels of geogenic $\mathrm{Gd}(0.002-0.004 \mu \mathrm{g} / \mathrm{L})$ and $\mathrm{Eu}(0.003-0.005 \mu \mathrm{g} / \mathrm{L})$,

\footnotetext{
${ }^{*} u_{R M}$ - reference material uncertainty; $u_{d}$ - sample digestion uncertainty; $u_{m}$ - measurement uncertainty by ICP-MS; $B$ - error of the obtained result relative to the certified value; $U_{c}$ - composite uncertainty; $U_{e}$ - expanded uncertainty significant at 0.05 probability level (extension coefficient $k=2$ )
} 
Table 1

Concentrations of selected trace metals and REE in the water samples of the Bobrza River and its left-bank tributary (Silnica River) upstream from the Nowiny wastewater treatment plant (samples collected on Nov. 27, 2013)

\begin{tabular}{|c|c|c|c|c|c|c|c|}
\hline \multirow{2}{*}{$\begin{array}{c}\text { Parameters } \\
\text { (As to } \mathrm{Lu} \text { in } \mu \mathrm{g} / \mathrm{L} \text { ) }\end{array}$} & \multicolumn{2}{|c|}{ Bobrza River } & \multicolumn{5}{|c|}{ Silnica River } \\
\hline & B4 & B5 & S1 & S2 & S3 & S4 & S5 \\
\hline $\mathrm{pH}$ & 7.2 & 7.3 & 7.7 & 7.8 & 7.7 & 7.6 & 7.6 \\
\hline $\mathrm{EC}(\mu \mathrm{S} / \mathrm{cm})$ & 375 & 374 & 596 & 572 & 687 & 470 & 649 \\
\hline $\mathrm{T}\left({ }^{\circ}\right)$ & 13.8 & 12.9 & 13.3 & 13.8 & 13.7 & 15.1 & 14.7 \\
\hline As & 0.78 & 0.78 & 1.16 & 1.20 & 1.36 & 1.13 & 1.00 \\
\hline $\mathrm{Cd}$ & 0.02 & 0.02 & 0.04 & 0.04 & 0.01 & 0.02 & 0.18 \\
\hline Co & 0.34 & 0.36 & 0.39 & 0.41 & 0.55 & 0.85 & 8.45 \\
\hline $\mathrm{Cr}$ & 2.19 & 1.92 & 2.86 & 3.50 & 3.42 & 2.59 & 2.96 \\
\hline $\mathrm{Cu}$ & 1.81 & 1.72 & 3.22 & 2.65 & 2.73 & 3.57 & 13.69 \\
\hline $\mathrm{Mn}$ & 114 & 124 & 30 & 48 & 140 & 262 & 1149 \\
\hline $\mathrm{Pb}$ & 0.50 & 0.74 & 0.40 & 0.16 & 0.14 & 0.13 & 0.13 \\
\hline $\mathrm{Zn}$ & 14 & 16 & 31 & 30 & 13 & 2.13 & 12 \\
\hline Sc & 2.492 & 2.247 & 2.643 & 2.460 & 1.975 & 1.600 & 2.101 \\
\hline $\mathrm{Y}$ & 0.057 & 0.080 & 0.048 & 0.065 & 0.048 & 0.079 & 0.307 \\
\hline $\mathrm{La}$ & 0.024 & 0.023 & 0.024 & 0.024 & 0.003 & 0.025 & 0.004 \\
\hline $\mathrm{Ce}$ & 0.042 & 0.043 & 0.064 & 0.013 & 0.066 & 0.063 & 0.053 \\
\hline $\mathrm{Pr}$ & 0.027 & 0.007 & 0.007 & 0.006 & 0.007 & 0.001 & 0.004 \\
\hline $\mathrm{Nd}$ & 0.057 & 0.081 & 0.049 & 0.014 & 0.023 & 0.053 & 0.099 \\
\hline $\mathrm{Sm}$ & 0.004 & 0.005 & 0.016 & 0.004 & 0.005 & 0.002 & 0.018 \\
\hline $\mathrm{Eu}$ & 0.015 & 0.015 & 0.014 & 0.012 & 0.026 & 0.010 & 0.017 \\
\hline $\mathrm{Gd}$ & 0.001 & 0.004 & 0.001 & 0.007 & 0.002 & 0.003 & 0.026 \\
\hline $\mathrm{Tb}$ & 0.007 & 0.001 & 0.001 & 0.001 & 0.001 & 0.004 & 0.005 \\
\hline Dy & 0.005 & 0.024 & 0.013 & 0.013 & 0.013 & 0.020 & 0.035 \\
\hline $\mathrm{Ho}$ & 0.003 & 0.004 & 0.003 & 0.003 & 0.003 & 0.004 & 0.006 \\
\hline $\mathrm{Er}$ & 0.002 & 0.004 & 0.001 & 0.007 & 0.014 & 0.011 & 0.015 \\
\hline $\mathrm{Tm}$ & 0.001 & 0.002 & 0.003 & 0.003 & 0.002 & 0.003 & 0.004 \\
\hline $\mathrm{Yb}$ & 0.007 & 0.011 & 0.007 & 0.017 & 0.017 & 0.011 & 0.035 \\
\hline $\mathrm{Lu}$ & 0.001 & 0.002 & 0.002 & 0.004 & 0.003 & 0.004 & 0.006 \\
\hline$\sum$ REEs (La-Lu) & 0.196 & 0.226 & 0.205 & 0.128 & 0.185 & 0.214 & 0.327 \\
\hline
\end{tabular}

largely contributing to the bedrock mineralogy and lithology (Salminen et al., 2005). Based on the new petrologic diagrams and interpolated maps of REE spatial distribution patterns in soils and surface water sediments throughout Europe, prepared by Forum of European Geological Surveys (FOREGS), Fedele et al. (2008) identified three REE baseline concentration ranges related to regional geologic/geomorphologic features. One of these groups is represented by low to very low values for REE in subsoils of the Netherlands, Germany and Poland (0.03-0.91 $\mathrm{mg} / \mathrm{kg}$ for Eu and $0.05-3.07 \mathrm{mg} / \mathrm{kg}$ for $\mathrm{Gd}$ ). This also suggests that the REE signatures of stream sediments and waters generally reflect bedrock mineralogy and lithology.

The low $\mathrm{Sm}_{\text {NASC }} / \mathrm{Yb}_{\text {NASC }}$ ratio $(0.125-0.500)$ in nearly all the river water samples indicates that LREE are scavenged by colloids. The wastewater treatment process does not change this ratio, which is evidenced by the same range values in the NWWTP effluents $(0.250-0.500)$.

\section{EUROPIUM POSITIVE ANOMALY IN Gd-UNCONTAMINATED RIVERS}

The NASC-normalized concentration patterns of REE upstream the rivers Silnica (S1 through S5), Bobrza (B4, B5) and downstream the rivers Czarna Nida (CN) and Nida (N1 through N6) are summarized in Figure 2. The sampling points N1 through N6 display nearly the same REE profiles; therefore, for the sake of brevity only the shale-normalized mean concentration pattern is presented (Fig. 2C). All these river waters show a distinct positive Eu anomaly with a weak negative Er anomaly and some minor anomalous excursions of other HREE, which may be characteristic of regional carbonate formations. It should be stressed that the distinct positive Eu anomaly was also noted in terrigenous rocks and sediments, and some agricultural waters of the Podwiśniówka area located about $5 \mathrm{~km}$ north of Kielce (Migaszewski et al., 2014). The Eu anomaly was computed from the equation (1):

$$
\mathrm{Eu} / \mathrm{Eu}_{\mathrm{NASC}}{ }^{*}=\mathrm{Eu}_{\mathrm{NASC}} /\left(\mathrm{Sm}_{\mathrm{NASC}} \times \mathrm{Gd}_{\mathrm{NASC}}\right)^{0.5}
$$

where: $\mathrm{Eu}_{\mathrm{NASC}}{ }^{*}$ - naturally-occurring (geogenic) background concentration whereas $\mathrm{Sm}_{\text {NASC }}$ and Gd $\mathrm{d}_{\text {NASC }}$ - NASC-normalized Sm and $\mathrm{Gd}$ concentrations, respectively.

The Eu anomaly in the examined stream waters was highly variable and $\mathrm{Eu} / \mathrm{Eu}_{\mathrm{NASC}}$ ratios varied from 0.92 to 29.70 with a 
Ta ble 2

Concentrations of selected trace metals and REE in the water samples of Nowiny wastewater treatment plant and downstream the Bobrza River

\begin{tabular}{|c|c|c|c|c|c|c|c|c|}
\hline \multirow[b]{2}{*}{$\begin{array}{c}\text { Parameters } \\
\text { (As to } L u \text { in } \mu \mathrm{g} / \mathrm{L} \text { ) }\end{array}$} & \multicolumn{4}{|c|}{ Nowiny wastewater treatment plant } & \multicolumn{4}{|c|}{ Bobrza River } \\
\hline & $\begin{array}{c}\text { NWWTP1 } \\
\text { Oct.23 } \\
2013\end{array}$ & $\begin{array}{c}\text { NWWTP2 } \\
\text { Nov. } 27 \\
2013\end{array}$ & $\begin{array}{c}\text { NWWTP3 } \\
\text { Jan.23 } \\
2014\end{array}$ & $\begin{array}{c}\text { NWWTP4 } \\
\text { Apr.8 } \\
2014\end{array}$ & $\begin{array}{c}\text { B3a } \\
\text { Oct.23 } \\
2013\end{array}$ & $\begin{array}{c}\text { B3b } \\
\text { Nov.27 } \\
2013\end{array}$ & $\begin{array}{c}\text { B3c } \\
\text { Jan.23 } \\
2014\end{array}$ & $\begin{array}{c}\text { B2a } \\
\text { Jan.23 } \\
2014\end{array}$ \\
\hline $\mathrm{pH}$ & n.d. & 6.9 & 7.0 & 7.0 & n.d. & 7.2 & 7.4 & 7.3 \\
\hline $\mathrm{EC}(\mu \mathrm{S} / \mathrm{cm})$ & n.d. & 962 & 1196 & 1170 & n.d. & 497 & 865 & 442 \\
\hline Eh $(\mathrm{mV})$ & n.d. & n.d. & -4.6 & -5.0 & n.d. & n.d. & -25.7 & -12.3 \\
\hline TDS (mg/L) & n.d. & n.d. & 600 & 587 & n.d. & n.d. & 433 & 222 \\
\hline Salinity (\%) & n.d. & n.d. & 0.6 & 0.6 & n.d. & n.d. & 0.4 & 0.2 \\
\hline $\mathrm{T}\left({ }^{\circ}\right)$ & n.d. & 12.7 & 13.9 & 16.6 & n.d. & 12.2 & 14.0 & 12.3 \\
\hline As & 0.80 & 1.09 & 1.24 & 2.61 & 0.8 & 1.12 & 1.08 & 1.06 \\
\hline $\mathrm{Cd}$ & 0.01 & 0.01 & 0.01 & 0.02 & 0.02 & 0.02 & 0.03 & 0.03 \\
\hline Co & 0.80 & 0.70 & 0.70 & 0.69 & 0.54 & 0.61 & 0.57 & 0.45 \\
\hline $\mathrm{Cr}$ & 9.70 & 5.86 & 8.50 & 5.94 & 5.80 & 2.64 & 5.81 & 2.64 \\
\hline $\mathrm{Cu}$ & 1.50 & 1.71 & 2.35 & 2.64 & 4.70 & 2.90 & 0.25 & 3.40 \\
\hline $\mathrm{Mn}$ & 61 & 75 & 97 & 104 & 55 & 149 & 141 & 50 \\
\hline $\mathrm{Pb}$ & 0.37 & 0.20 & 0.40 & 0.77 & 1.49 & 1.52 & 4.17 & 0.91 \\
\hline $\mathrm{Zn}$ & 40 & 85 & 68 & 26 & 16 & 24 & 30 & 31 \\
\hline $\mathrm{Sc}$ & 1.030 & 3.809 & 3.542 & 4.359 & 0.093 & 2.921 & 2.838 & 3.307 \\
\hline$Y$ & 0.040 & 0.007 & 0.026 & 0.014 & 0.060 & 0.118 & 0.080 & 0.082 \\
\hline La & 0.018 & 0.023 & 0.008 & 0.035 & 0.051 & 0.076 & 0.020 & 0.026 \\
\hline $\mathrm{Ce}$ & 0.016 & 0.064 & 0.012 & 0.076 & 0.080 & 0.063 & 0.053 & 0.058 \\
\hline $\mathrm{Pr}$ & 0.004 & 0.007 & 0.003 & 0.019 & 0.009 & 0.005 & 0.018 & 0.007 \\
\hline $\mathrm{Nd}$ & 0.008 & 0.026 & 0.021 & 0.044 & 0.117 & 0.035 & 0.014 & 0.050 \\
\hline $\mathrm{Sm}$ & 0.001 & 0.004 & 0.002 & 0.007 & 0.022 & 0.012 & 0.046 & 0.003 \\
\hline $\mathrm{Eu}$ & 0.001 & 0.005 & 0.005 & 0.001 & 0.015 & 0.005 & 0.008 & 0.007 \\
\hline $\mathrm{Gd}$ & 0.516 & 0.378 & 0.386 & 0.254 & 0.160 & 0.096 & 0.102 & 0.102 \\
\hline $\mathrm{Tb}$ & 0.001 & 0.001 & 0.002 & 0.005 & 0.002 & 0.002 & 0.001 & 0.001 \\
\hline Dy & 0.004 & 0.014 & 0.015 & 0.003 & 0.007 & 0.021 & 0.033 & 0.019 \\
\hline $\mathrm{Ho}$ & 0.003 & 0.002 & 0.001 & 0.002 & 0.002 & 0.011 & 0.004 & 0.009 \\
\hline $\mathrm{Er}$ & 0.005 & 0.001 & 0.002 & 0.005 & 0.003 & 0.012 & 0.012 & 0.002 \\
\hline $\mathrm{Tm}$ & 0.003 & 0.001 & 0.006 & 0.001 & 0.001 & 0.001 & 0.003 & 0.002 \\
\hline $\mathrm{Yb}$ & 0.008 & 0.005 & 0.018 & 0.011 & 0.016 & 0.022 & 0.020 & 0.007 \\
\hline $\mathrm{Lu}$ & 0.002 & 0.001 & 0.004 & 0.001 & 0.002 & 0.004 & 0.004 & 0.001 \\
\hline ¿REEs (La-Lu) & 0.590 & 0.532 & 0.485 & 0.464 & 0.487 & 0.365 & 0.338 & 0.294 \\
\hline
\end{tabular}

n.d. - not determined

mean of 8.05 (Table 4). The lowest values were noted in the NWWTP (0.27) and downstream the Bobrza River (0.92-2.65). In contrast, the highest Eu/Eu* ${ }_{\text {NASC }}$ ratios (3.61-29.70, mean of 12.51) were recorded in the Gd-uncontaminated waters upstream from the NWWTP. For comparison, about 500 streams of Eastern Canada exhibited (Eu/EunASC $\left.{ }^{*}\right)$ in the range of 0.295 to 1.77 , with a mean of 0.764 (Leybourne and Johannesson, 2008). These authors also suggest that Eu is relatively more mobile compared to other REE and is more easily released from minerals and rocks. However, it is interesting to note that the examined stream waters do not show a negative $\mathrm{Ce}$ anomaly recorded in somewhat acidic farmer's well waters north of Kielce (Migaszewski et al., 2014). This may indicate a lack of mobility of $\mathrm{Ce}^{4+}$ in a somewhat alkaline environment.

The lack of $\mathrm{Gd}$ anomaly upstream from the NWWTP also excludes the leakage of municipal sewage from the sanitary collector sewer into the Silnica River. Moreover, there are no La and $\mathrm{Sm}$ anomalies that might indicate unauthorized wastewater discharges from various manufacturing plants or facilities (Kulaksız and Bau, 2013).

\section{GADOLINIUM AS AN ANTHROPOGENIC MICROPOLLUTANT TRACER}

The NASC-normalized concentration patterns of REE in the NWWTP effluents show a very strong positive $\mathrm{Gd}$ anomaly with very weak positive Tm and Lu excursions (Fig. 3A). The same roof-shaped pattern was recorded during four measurement series regardless of $\mathrm{Gd}$ levels. Some variations in $\mathrm{Gd}$ concentrations may be linked to the variable schedule of medical MRI facilities, or to the weekday of sampling. According to different authors, Thursday or Friday is the best option for tracing Gd signatures in waters (e.g., Möller et al., 2003). This is also evidenced by lower levels of Gd in wastewater sample NWWTP4 that was collected on Tuesday (April 8 of 2014; Table 2). The anthropogenic influence of the NWWTP is evident downstream the Bobrza River at sampling points B3 and B2 (Fig. 3B), located about 0.5 and $6 \mathrm{~km}$ of the NWWTP. The REE profiles are generally similar to those of the NWWTP effluents with a predominant strong positive Gd anomaly, subordinate positive Eu, $\mathrm{Ho}, \mathrm{Tm}$ and Sm anomalies, and a weak negative $\mathrm{Er}$ anomaly. The sampling point B1, which is located near the estuary of the 
Concentrations of selected trace metals and REE in the waters downstream the rivers Bobrza, Czarna Nida and Nida (samples collected on April 8 of 2014)

\begin{tabular}{|c|c|c|c|c|c|c|c|c|c|c|}
\hline \multirow{2}{*}{$\begin{array}{c}\text { Parameters } \\
\text { (As to } \mathrm{Lu} \text { in } \mu \mathrm{g} / \mathrm{L} \text { ) }\end{array}$} & \multicolumn{3}{|c|}{ Bobrza River } & \multirow{2}{*}{$\begin{array}{c}\text { Cz. Nida R. } \\
\text { CN }\end{array}$} & \multicolumn{6}{|c|}{ Nida River } \\
\hline & B3d & B2b & B1 & & N6 & N5 & N4 & N3 & $\mathrm{N} 2$ & N1 \\
\hline $\mathrm{pH}$ & 7.5 & 8.0 & 7.9 & 7.9 & 8.0 & 8.1 & 8.1 & 8.1 & 8.1 & 8.0 \\
\hline $\mathrm{EC}(\mu \mathrm{S} / \mathrm{cm})$ & 634 & 632 & 538 & 543 & 493 & 499 & 554 & 555 & 566 & 598 \\
\hline Eh $(\mathrm{mV})$ & -34.0 & -60.8 & -55.7 & -54.1 & -62.0 & -65.0 & -65.1 & -66.4 & -65.6 & -64.6 \\
\hline TDS (mg/L) & 317 & 315 & 266 & 270 & 246 & 250 & 277 & 277 & 283 & 298 \\
\hline Salinity (\%) & 0.3 & 0.3 & 0.2 & 0.2 & 0.2 & \begin{tabular}{|l|}
0.2 \\
\end{tabular} & 0.2 & 0.2 & 0.2 & 0.2 \\
\hline $\mathrm{T}\left({ }^{\circ}\right)$ & 17.1 & 21.8 & 20.2 & 21.0 & 21.9 & 21.8 & 22.0 & 21.9 & 21.6 & 21.9 \\
\hline As & 1.39 & 1.26 & 1.36 & 0.98 & 0.90 & 0.88 & 0.93 & 1.05 & 0.94 & 0.93 \\
\hline $\mathrm{Cd}$ & 0.02 & 0.04 & 0.03 & 0.01 & 0.01 & 0.01 & 0.18 & 0.01 & 0.01 & 0.01 \\
\hline Co & 0.43 & 0.40 & 0.35 & 0.41 & 0.25 & 0.26 & 0.27 & 0.28 & 0.30 & 0.33 \\
\hline $\mathrm{Cr}$ & 5.60 & 5.91 & 5.87 & 5.75 & 5.67 & 5.78 & 6.37 & 6.39 & 6.35 & 6.37 \\
\hline $\mathrm{Cu}$ & 0.64 & 1.28 & 0.98 & 0.24 & 0.25 & 0.29 & 0.27 & 0.28 & 0.26 & 0.28 \\
\hline $\mathrm{Mn}$ & 91 & 53 & 62 & 71 & 22 & 23 & 23 & 23 & 22 & 27 \\
\hline $\mathrm{Pb}$ & 0.06 & 0.45 & 0.20 & 0.08 & 0.06 & 0.07 & 0.05 & 0.06 & 0.05 & 0.06 \\
\hline $\mathrm{Zn}$ & 9 & 12 & 13 & 5 & 0.83 & 0.94 & 0.83 & 0.90 & 0.89 & 0.88 \\
\hline $\mathrm{Y}$ & 0.045 & 0.048 & 0.040 & 0.054 & 0.040 & 0.043 & 0.030 & 0.047 & 0.063 & 0.048 \\
\hline Sc & 2.886 & 2.825 & 2.812 & 2.571 & 3.340 & 3.195 & 3.313 & 3.888 & 3.381 & 3.985 \\
\hline $\mathrm{La}$ & 0.019 & 0.013 & 0.002 & 0.002 & 0.004 & 0.047 & 0.028 & 0.044 & 0.049 & 0.046 \\
\hline $\mathrm{Ce}$ & 0.009 & 0.102 & 0.107 & 0.107 & 0.087 & 0.088 & 0.086 & 0.083 & 0.122 & 0.087 \\
\hline $\mathrm{Pr}$ & 0.011 & 0.025 & 0.023 & 0.024 & 0.005 & 0.023 & 0.023 & 0.022 & 0.026 & 0.022 \\
\hline $\mathrm{Nd}$ & 0.053 & 0.049 & 0.045 & 0.046 & 0.024 & 0.051 & 0.052 & 0.050 & 0.049 & 0.049 \\
\hline $\mathrm{Sm}$ & 0.004 & 0.001 & 0.005 & 0.004 & 0.003 & 0.001 & 0.002 & 0.002 & 0.002 & 0.003 \\
\hline $\mathrm{Eu}$ & 0.012 & 0.003 & 0.009 & 0.006 & 0.006 & 0.006 & 0.006 & 0.007 & 0.011 & 0.006 \\
\hline $\mathrm{Gd}$ & 0.060 & 0.046 & 0.036 & 0.015 & 0.019 & 0.004 & 0.009 & 0.006 & 0.008 & 0.003 \\
\hline $\mathrm{Tb}$ & 0.002 & 0.001 & 0.001 & 0.002 & 0.003 & 0.001 & 0.004 & 0.003 & 0.002 & 0.002 \\
\hline Dy & 0.011 & 0.003 & 0.013 & 0.013 & 0.007 & 0.008 & 0.005 & 0.005 & 0.006 & 0.008 \\
\hline $\mathrm{Ho}$ & 0.004 & 0.002 & 0.003 & 0.004 & 0.004 & 0.004 & 0.004 & 0.004 & 0.004 & 0.003 \\
\hline $\mathrm{Er}$ & 0.007 & 0.005 & 0.001 & 0.005 & 0.005 & 0.001 & 0.006 & 0.005 & 0.006 & 0.002 \\
\hline $\mathrm{Tm}$ & 0.002 & 0.002 & 0.002 & 0.001 & 0.002 & 0.002 & 0.002 & 0.001 & 0.001 & 0.001 \\
\hline $\mathrm{Yb}$ & 0.008 & 0.005 & 0.008 & 0.001 & 0.014 & 0.004 & 0.008 & 0.008 & 0.008 & 0.008 \\
\hline Lu & 0.001 & 0.001 & 0.001 & 0.001 & 0.002 & 0.002 & 0.001 & 0.002 & 0.001 & 0.001 \\
\hline$\sum$ REEs (La-Lu) & 0.203 & 0.258 & 0.256 & 0.231 & 0.185 & 0.242 & 0.236 & 0.242 & 0.295 & 0.241 \\
\hline
\end{tabular}

Bobrza River about $11 \mathrm{~km}$ of the NWWTP, exhibits a distinct positive double $\mathrm{Gd}$ and Eu anomaly that may also point out to significant input of REE from geogenic sources (bedrock mineralogy and lithology) into surface waters (Fig. 3B).

\section{ANTHROPOGENIC VS. GEOGENIC GADOLINIUM}

The crucial issue in geochemistry and environmental sciences is evaluation of geochemical background that can be used for environmental risk assessment and setting of pollutant regulatory levels (Gałuszka, 2007 and reference therein). In case of gadolinium the best method to evaluate natural (geogenic) background concentration is to interpolate values derived from the shale-normalized $\mathrm{Sm}$ and $\mathrm{Tb}$ (Eu was avoided due to predominating positive Eu anomaly in natural waters). The $\mathrm{Gd}$ anomaly $\left(\mathrm{Gd}_{\text {NASC }} / \mathrm{Gd}_{\text {NASC }}{ }^{*}\right)$ can be calculated from the equation (2) (Bau et al., 2006):

$$
\begin{gathered}
\mathrm{Gd}_{\text {anomaly }}=G \mathrm{~d}_{\text {NASC }} / \mathrm{Gd}_{\text {NASC }}{ }^{*}=\mathrm{Gd}_{\text {NASC }} /\left(0.33 S m_{\text {NASC }}+[2]\right. \\
\left.0.67 \mathrm{~Tb}_{\text {NASC }}\right)
\end{gathered}
$$

where: $\mathrm{Gd}_{\text {NASC }}{ }^{*}$ - naturally-occurring (geogenic) background concentration whereas $\mathrm{Sm}_{\text {NASC }}$ and $\mathrm{Tb}_{\text {NASC }}$ are the NASC-normalized $\mathrm{Sm}$ and $\mathrm{Tb}$ concentrations, respectively.

The highest $\mathrm{Gd}_{\text {NASC }} / \mathrm{Gd}_{\text {NASC }}{ }^{*}$ ratio averaging 32.34 was noted in the NWWTP effluents (Table 4). This is due to the fact that during wastewater treatment the Gd compounds do not undergo biodegradation and remain in the effluent. The anionic Gd-DTPA (Magnevist, gadolinium-diethylenetriaminepentaacetic acid) or nonionic Gd-BT-DO3A (Gadovist, gadobutrol) complexes are not adsorbed onto the surfaces of suspended clay minerals or organic matter, and are not ion exchanged or co-precipitated (Bau and Dulski, 1996; Elbaz-Poulichet et al., 2002; Morteani et al., 2006; Künnemeyer et al., 2009), hence they are stable for at least 6 months in natural aqueous environments (Knappe et al., 2005). It is worth mentioning that the $\mathrm{Gd}_{\mathrm{SN}} / \mathrm{Gd}_{\mathrm{SN}}{ }^{*}$ ratio in the effluents of the largest WWTP "Ruhleben" in Berlin varied from 207 to 2014 (Knappe et al., 2005).

The $\mathrm{Gd}_{\text {NASC }} / \mathrm{Gd}_{\text {NASC }}$ * ratios in the examined river waters varied from 0.23 to 15.57 (Table 4). The upstream river waters (B4, 

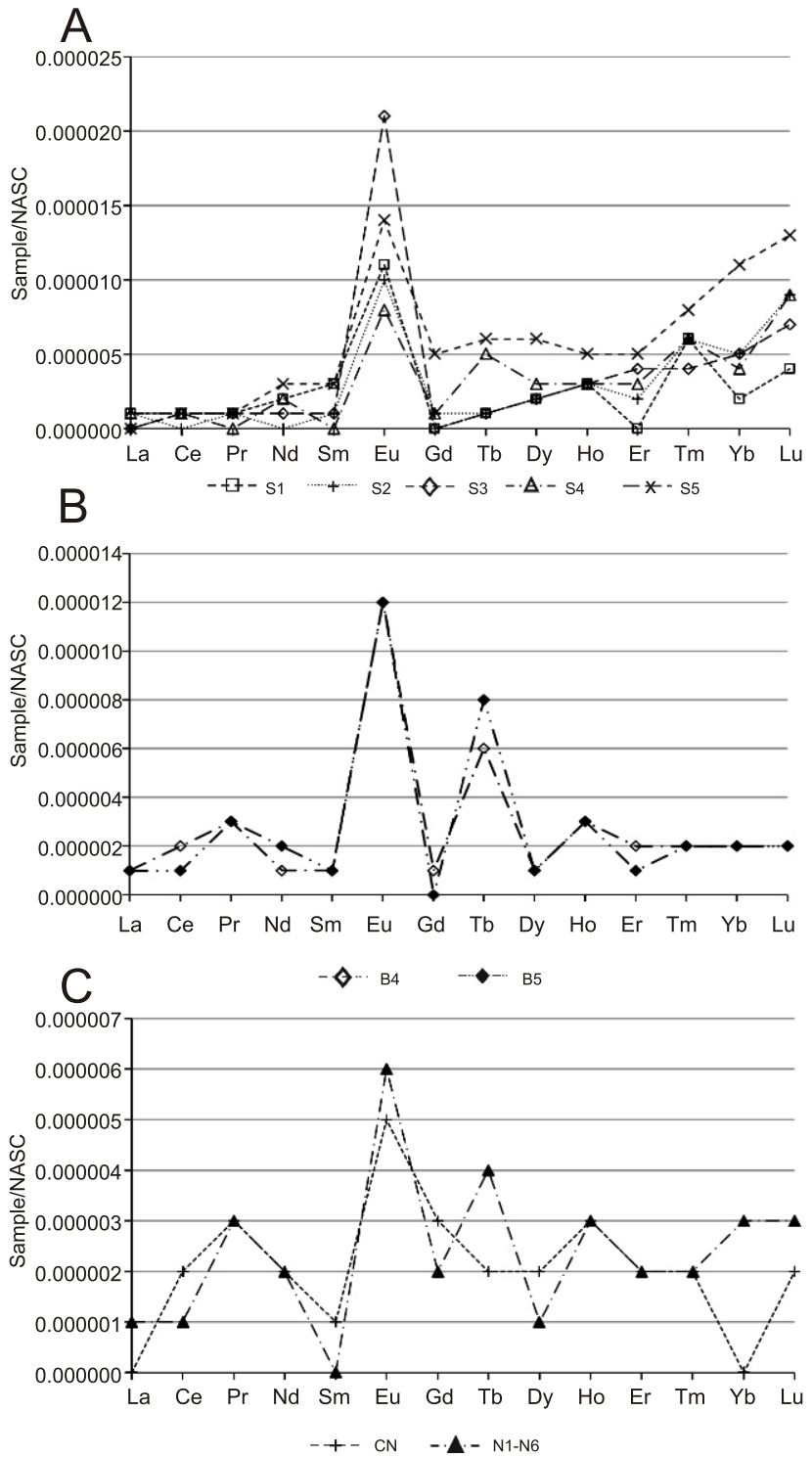

Fig. 2. NASC-normalized REE concentration patterns for upstream and downstream water samples

A - Silnica River (S1-S5), B - Bobrza River (B4, B5), C - rivers Czarna Nida (CN) and Nida (N1-N6)
B5, S1-S5) and the Nida River waters (except for N5) showed low $\mathrm{Gd}$ anomalies $(\leq 1.00)$. The positive $\mathrm{Gd}$ anomaly lower than 1.1 points out to geogenic origin of this element (Lawrence et al., 2006). This indicates that the lower reaches of the Bobrza River (B3, B2, B1) and the Czarna Nida River (CN) are influenced primarily by effluents discharged from the NWWTP. They cover a distance of about $15 \mathrm{~km}$. A more pronounced positive $\mathrm{Gd}$ anomaly at sampling point B2 $\left(\mathrm{Gd}_{\text {NASC }} / \mathrm{Gd}_{\text {NASC }}{ }^{*}=\right.$ 15.57 ) is induced from overlapping effluents derived from the NWWTP and local wastewater treatment plant at Radkowice. In addition, a weak positive $\mathrm{Gd}$ anomaly was also found at sampling point N5 downstream from a small tributary Brzeźnica (Table 4). This anomaly pinpoints diluted effluents from Jędrzejów WWTP located about $15 \mathrm{~km}$ west of N5 (Fig. 1). For comparison, the $\mathrm{Gd}_{\text {PAAS }} / \mathrm{Gd}_{\text {PAAS }}{ }^{*}$ ratios in the rivers of Pennsylvania (Ohio, Beaver, Allegheny, Monongahela, Juniata, Susquehanna) varied from 1.15 to 1.47 (Bau et al., 2006), but much higher values were noted in the rivers Wupper (30) and Havel (126), Germany (Bau and Dulski, 1996).

It should be stressed that these results depend not only on $\mathrm{Gd}_{\text {anth }}$ contents, but also on $\mathrm{Gd}^{*}$ levels. It is noteworthy that geogenic background element concentrations may also show spatial and temporal variability which is influenced by different environmental factors, for example by the amount of precipitation, suspended matter etc.

The contribution of anthropogenic gadolinium $\left(\mathrm{Gd}_{\text {anth }}\right)$ to the total gadolinium pool is calculated from the equation (3) (Schwesig and Bergmann, 2011; European Commission, 2012):

$$
\mathrm{Gd}_{\text {anth }}=\left[\left(\mathrm{Gd}_{\text {anomaly }}-1\right) / \mathrm{Gd}_{\text {anomaly }}\right] \times \mathrm{Gd}_{\text {measured }}
$$

The results indicate that the input of anthropogenic gadolinium was in the range 94 to $44 \%$ downstream from the NWWTP (B3 through CN). This amounted to $16 \%$ at sampling point N5. The largest input of $\mathrm{Gd}_{\text {anth }}(97 \%)$ was noted at the NWWTP. In other more industrialized areas gadolinium was easily measured in the river waters at a distance of above $50 \mathrm{~km}$ downstream from Wetalla WWTP and up to $3 \%$ wastewaters were traced up to $100 \mathrm{~km}$ away from the point pollution source (Lawrence and Bariel, 2010). Assuming that current processing capacity of the NWWTP is about $55000 \mathrm{~m}^{3} /$ day and the contents of $\mathrm{Gd}$ in effluents vary from 0.254 to $0.516 \mu \mathrm{g} / \mathrm{L}$, the total discharge of $\mathrm{Gd}$ into the surface water is in the range of about 13-27 g/day. For comparison, the total daily $\mathrm{Gd}$ input of 7 WWTP in Berlin was about $178 \mathrm{~g}$ (Knappe et al., 2005).

The relationship between NASC-normalized gadolinium and europium in the Nida River watershed is summarized in Figure 4. The extent of pronounced Gd anomaly surpassing Eu anomaly is traced at sampling points B3 and B2, reaching equi-

$\mathrm{Eu} / \mathrm{Eu}^{*}$ and $\mathrm{Gd}_{\mathrm{NASC}} / \mathrm{Gd}_{\mathrm{NASC}}{ }^{*}$ ratios and contribution of anthropogenic gadolinium (Ganth) in the waters examined

\begin{tabular}{|l|c|c|c|c|c|c|c|c|c|c|c|c|c|c|c|c|c|c|}
\hline Sampling points & S5 & S4 & S3 & S2 & S1 & B5 & B4 & NWWTP & B3 & B2 & B1 & CN & N6 & N5 & N4 & N3 & N2 & N1 \\
\hline Eu/Eu $^{*}$ & 3.61 & 11.31 & 29.70 & 10.00 & 8.98 & 12.00 & 12.00 & 0.27 & 0.92 & 1.57 & 2.65 & 2.89 & 2.87 & 7.07 & 5.00 & 8.48 & 12.73 & 5.00 \\
\hline Gd $_{\text {NASC }} / G_{\text {NASC }}$ & 1.00 & 0.28 & 0.50 & 1.00 & 0.30 & 1.00 & 0.23 & 32.34 & 7.14 & 15.57 & 7.00 & 1.80 & 1.00 & 1.20 & 0.57 & 0.35 & 0.66 & 0.60 \\
\hline Gd $_{\text {anth }}[\%]$ & - & - & - & - & - & - & - & 97 & 86 & 94 & 86 & 44 & - & 16 & - & - & - & - \\
\hline
\end{tabular}

$\mathrm{Eu} / \mathrm{Eu}^{*}=\mathrm{Eu}_{\mathrm{NASC}} /\left(\mathrm{Sm}_{\mathrm{NASC}} \times \mathrm{Gd}_{\mathrm{NASC}}\right)^{0.5} ; \mathrm{Gd}_{\mathrm{NASC}} / \mathrm{Gd}_{\mathrm{NASC}}{ }^{*}=\mathrm{Gd}_{\mathrm{NASC}} /\left(0.33 \mathrm{Sm}_{\mathrm{NASC}}+0.67 \mathrm{~Tb}_{\mathrm{NASC}}\right) ; \mathrm{Gd}_{\text {anth }}=\left[\left(\mathrm{Gd}_{\text {anomaly }}-1\right) / \mathrm{Gd}_{\text {anomaly }}\right] \times \mathrm{Gd}_{\text {measured }}$ 

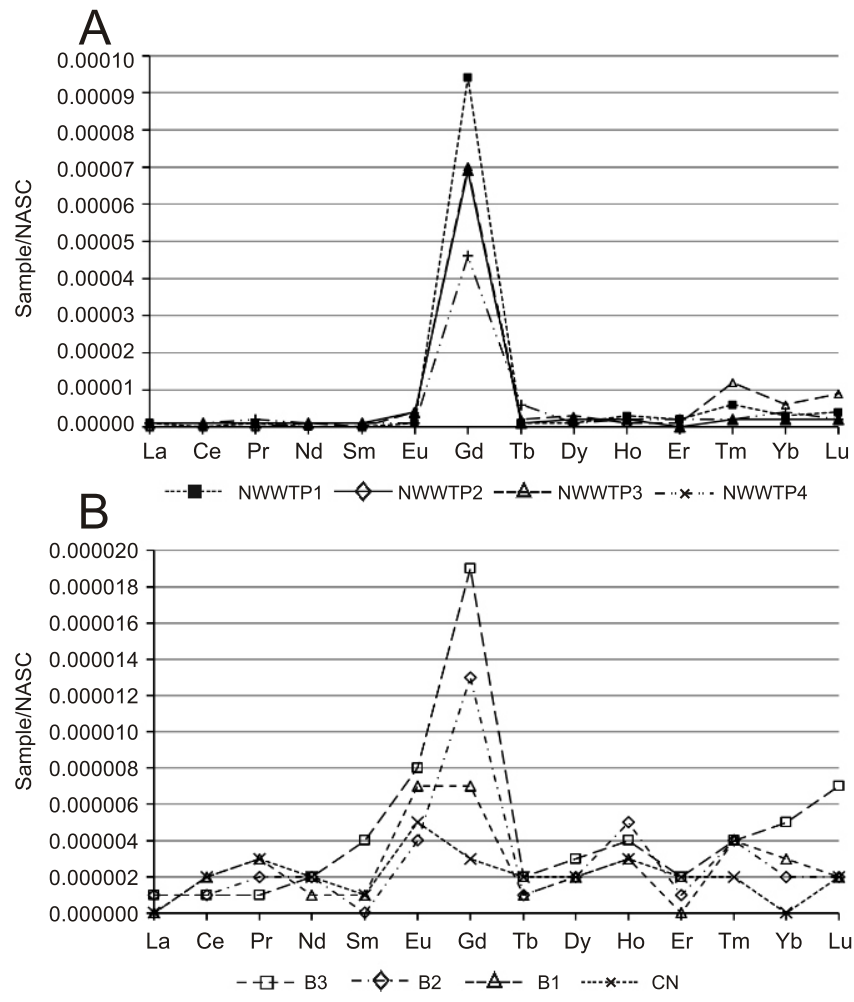

Fig. 3. NASC-normalized REE concentration patterns for

A - Nowiny wastewater treatment plant (NWWTP) effluents; B Bobrza and Czarna Nida rivers downstream of NWWTP (sampling points B3-B1, CN); REE-profile B3 - mean of 4 measurements, REE-profile B2 - mean of 3 measurements

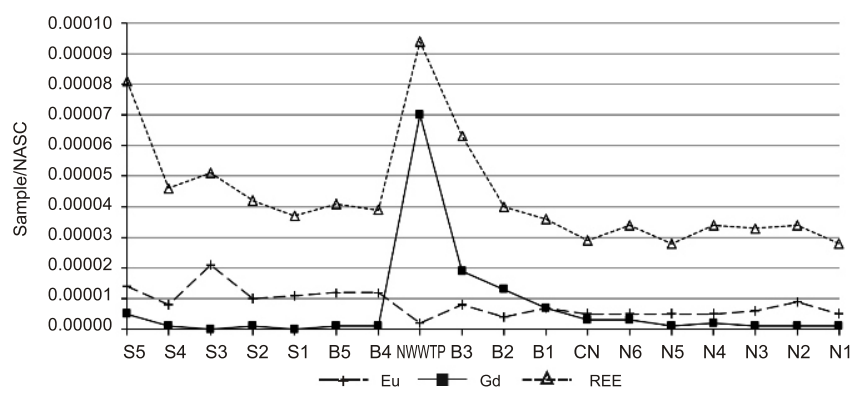

Fig. 4. Comparison of NASC-normalized concentration patterns of Gd, Eu and total REE concentrations in the Nida River drainage system librium at point B1. In the other stretches of the Nida River Eu prevails over $\mathrm{Gd}$.

\section{CONCLUSIONS}

The results derived from this study enable drawing the following conclusions:

1. The principal source of anthropogenic gadolinium in the Nida River drainage system of the study area is the NWWTP. Its effluents are characterized by the highest $\mathrm{Gd}_{\text {NASC }} / \mathrm{Gd}_{\text {NASC }}$ * ratio (32.34) and $\mathrm{Gd}_{\text {anth }}$ input (97\%) as well as the lowest $\mathrm{Eu} / \mathrm{Eu}^{*}$ ratio $(0.27)$.

2. The NWWTP effluents range over $15 \mathrm{~km}$ downstream of the treatment plant in the Bobrza and Czarna Nida rivers, which is evidenced by the $\mathrm{Gd}_{\text {NASC }} / \mathrm{Gd}_{\text {NASC }}{ }^{*}$ ratio above 1.1 (1.80-15.57) and the $\mathrm{Gd}_{\text {anth }}$ input (44-94\%). Distinctly higher values of these parameters at sampling point $B 2$ indicate mixing of wastewaters discharged from the NWWTP and local Radkowice WWTP. A weak $\mathrm{Gd}_{\text {anth }}$ recorded in the Nida River (N5) suggests the inflow of effluents from another local Jędrzejów WWTP. All these wastewater treatment plants receive effluents from MRI hospital and medical facilities.

3. The NASC-normalized REE concentration patterns of Gd-uncontaminated rivers (Silnica, upstream Bobrza and major stretches of Nida) are highlighted by a pronounced Eu anomaly that exhibits a high Eu/Eu* ratio in the range of 2.87 to 29.70 . This anomaly is linked to regional bedrock mineralogy and lithology.

4. Variations in $\mathrm{Gd}_{\text {anth }}$ contents are primarily affected by the amount of $\mathrm{Gd}_{\mathrm{anth}}$-bearing effluents (including sampling day) and amount of precipitation (dilution effect). The NWWTP is supposed to discharge about $13-27 \mathrm{~g}$ of $\mathrm{Gd}_{\text {anth }}$ per day into the surface water system.

5. The results of this study do not point to the leakage of municipal sewage from the sanitary collector sewer into the Silnica River.

As indicated by this and other case studies, anthropogenic gadolinium is a micropollutant that enables tracing the extent of effluents discharged from wastewater treatment plants into surface waters. This element can also be used as a tracer of overlapping different WWTP wastewater inputs from tributaries of main rivers, or as a control indicator of potential leakage of municipal sewage systems. Another advantage is the fact that determination of $\mathrm{Gd}$ is a relatively rapid and cost-effective analysis compared to time-consuming and expensive determination of other pharmaceuticals (antibiotics, antihypertensives, antiinflammatories, antihistamines, estrogens) contained in medical effluents.

Acknowledgements. We are grateful to Dr. J. Prażak of the Polish Geological Institute - National Research Institute, Holy Cross Mountains Branch in Kielce and Dr. M.T. Aide of Southeast Missouri State University for reviewing this paper and for valuable remarks. We would like to extend the same thanks to Dr. P.J. Lamothe, a retired research chemist of the U.S. Geological Survey in Denver for his insightful comments that considerably improved the quality of the manuscript. 


\section{REFERENCES}

Barber, L.B., Furlong, E.T., Keefe, S.H., Brown, G.K., Cahill, J.D., 2003. Natural and contaminant organic compounds in the Boulder Creek Watershed, Colorado, during high-flow and low-flow conditions, 2000. In: Comprehensive Water Quality of the Boulder Creek Watershed, Colorado, During High-flow and Low-flow Conditions, 2000 S (eds. F. Murphy et al.): 103-144. U.S. Geological Survey Water-Resources Investigations Report, 03-4045.

Bau, M., Dulski, P., 1996. Anthropogenic origin of positive gadolinium anomalies in river waters. Earth and Planetary Science Letters, 143: 245-255.

Bau, M., Knappe, A., Dulski, P., 2006. Anthropogenic gadolinium as a micropollutant in river waters in Pennsylvania and in Lake Erie, northeastern United States. Chemie der Erde, 66: 143-152.

Elbaz-Poulichet, F., Seidel, J.-L., Othoniel, C., 2002. Occurrence of an anthropogenic gadolinium anomaly in river and coastal waters of Southern France. Water Research, 36: 1102-1105.

European Commission, 2012. EU Wide Monitoring Survey on Waste Water Treatment Plant Effluents. Analysis of Gadolinium anomaly as a measure of Gd-based contrasting agents (IWW Water Centre): 41-42.

Fedele, L., Plant, J.A., De Vivo, B., Lima, A., 2008. The rare earth element distribution over Europe: geogenic and anthropogenic sources. Geochemistry: Exploration, Environment, Analysis, 8 3-18.

Gałuszka, A., 2007. Different approaches in using and understanding the term "geochemical background" - practical implications for environmental studies. Polish Journal of Environmental Studies, 16: 389-395.

Gromet, L.P., Dymek, R.F., Haskin, L.A., Korotev, R.L., 1984. The "North American shale composite"; its compilation, major and trace element characteristics. Geochimica et Cosmochimica Acta, 48: 2469-2482.

Haskin, L.A., Wildeman, T.R., Haskin, M.A., 1968. An accurate procedure for the determination of the rare earths by neutron activation. Journal of Radioanalytical and Nuclear Chemistry, 1 : 337-348.

Idée, J-M., Port, M., Medina, C., Lancelot, E., Fayoux, E., Ballet, S., Corot, C., 2008. Possible involvement of gadolinium chelates in the pathophysiology of nephrogenic systemic fibrosis: a critical review. Toxicology, 248: 77-88.

Knappe, A., Möller, P., Dulski, P., Pekdeger, A., 2005. Positive gadolinium anomaly in surface water and ground water of the urban area Berlin, Germany. Chemie der Erde, 65: 167-189.

Kulaksız, S., Bau, M., 2007. Contrasting behaviour of the gadolinium and natural rare earth elements in estuaries and the gadolinium input into the North Sea. Earth and Planetary Science Letters, 260: 361-371.

Kulaksız, S., Bau, M., 2011. Anthropogenic gadolinium as a microcontaminant in tap water used as drinking water in urban areas and megacities. Applied Geochemistry, 26: 1877-1885.

Kulaksız, S., Bau, M., 2013. Anthropogenic dissolved and colloid/nanoparticle-bound samarium, lanthanum and gadolinium in the Rhine River and the impending destruction of the natural rare earth element distribution in rivers. Earth and Planetary Science Letters, 362: 43-50.

Kümmerer, K., Helmers, E., 2000. Hospital effluents as a source for gadolinium in the aquatic environment. Environmental Science and Technology, 34: 573-577.

Künnemeyer, J., Terborg, L., Meermann, B., Brauckmann, C., Möller, I., Scheffer, A., Karst, U., 2009. Speciation analysis of gadolinium chelates in hospital effluents and wastewater treatment plant sewage by a novel HILIC/ICP-MS method. Environmental Science and Technology, 43: 2884-2890.

Lawrence, M.G., 2010. Detection of anthropogenic gadolinium in the Brisbane River plume in Moreton Bay, Queensland, Australia. Marine Pollution Bulletin, 60: 1113-1116.
Lawrence, M.G., Bariel, D.G., 2010. Tracing treated wastewater in an inland catchment using anthropogenic gadolinium. Chemosphere, 80: 794-799.

Lawrence, M.G., Greig, A., Collerson, K.D., Kamber, B.S., 2006 Rare earth element and yttrium variability in South East Queensland waterways. Aquatic Geochemistry, 12: 39-72.

Lawrence, M.G., Ort, C., Keller, J., 2009. Detection of anthropogenic gadolinium in treated wastewater in South East Queensland, Australia. Water Research, 43: 3534-3540.

Leybourne, M.I., Johannesson, K.H., 2008. Rare earth elements (REE) and yttrium in stream waters, stream sediments, and $\mathrm{Fe}-\mathrm{Mn}$ oxyhydroxides: Fractionation, speciation, and controls over REE + Y patterns in the surface environment. Geochimica et Cosmochimica Acta, 72: 5962-5983.

Migaszewski, Z.M., Gałuszka, A., 2015. The characteristics, occurrence and geochemical behavior of rare earth elements in the environment: A review. Critical Reviews in Environmental Science and Technology, 45: 429-471.

Migaszewski, Z.M., Starnawska, E., Gałuszka, A., 2007. Gorceixite from the Upper Cambrian rocks of the Podwiśniówka mine pit, Holy Cross Mountains (south-central Poland). Mineralogia Polonica, 38: 171-184.

Migaszewski, Z.M., Gałuszka, A., Migaszewski, A., 2014. The study of rare earth elements in farmer's well waters of the Podwiśniówka acid mine drainage area (south-central Poland). Environmental Monitoring Assessment, 186: 1609-1622.

Morteani, G., Möller, P., Fuganti, A., Paces, T., 2006. Input and fate of anthropogenic estrogens and gadolinium in surface water and sewage plants in the hydrological basin of Prague (Czech Republic). Environmental Geochemistry and Health, 28: 257-264.

Möller, P., Dulski, P., 2010. Transmetallation of Gd-DTPA by Cu, Y and lanthanides and its impact on the hydrosphere. Applied Geochemistry, 25: 49-59.

Möller, P., Dulski, P., Bau, M., Knappe, A., Pekdeger, A. Sommer-von Jarmersted, C., 2000. Anthropogenic gadolinium as a conservative tracer in hydrology. Journal of Geochemical Exploration, 69-70: 409-414.

Möller, P., Paces, T., Dulski, P., Morteani, G., 2002. Anthropogenic Gd in surface water, drainage systems, and the water supply of the city of Prague, Czech Republic. Environmental Science and Technology, 36: 2387-2394.

Möller, P., Morteani, G., Dulski, P., 2003. Anomalous gadolinium, cerium, and yttrium contents in the Adige and Isarco river waters and in the water of their tributaries (provinces Trento and Bolzano/Bozen, NE Italy). Acta Hydrochimica et Hydrobiologica, 31: 225-239.

Nozaki, Y., Lerche, D., Alibo, D.S., Tsutsumi, M., 2000. Dissolved indium and rare earth elements in three Japanese rivers and Tokyo Bay: evidence for anthropogenic Gd and In. Geochimica et Cosmochimica Acta, 64: 3975-3982.

Petrosino, P., Sadeghi, M., Albanese, S., Andersson, M., Lima A., De Vivo, B., 2013. REE contents in solid sample media and stream water from different geological contexts: Comparison between Italy and Sweden. Journal of Geochemical Exploration, 133: 176-201.

Rabiet, M., Brissaud, F., Seidel, J.L., Pistre, S., Elbaz-Poulichet, F., 2009. Positive gadolinium anomalies in wastewater treatment plant effluents and aquatic environment in the Hérault watershed (South France). Chemosphere, 75: 1057-1064.

Rubinowski, Z., Kowalczewski, Z., Lenartowicz, L., Wróblewski, T., 1966. Metalogeneza trzonu paleozoicznego Gór Świętokrzyskich. Prace Instytutu Geologicznego.

Salminen, R., ed., 2005. Geochemical Atlas of Europe: part 1, Background Information, Methodology and Maps. FOREGS.

Schwesig, D., Bergmann, A., 2011. Use of anthropogenic gadolinium as a tracer for bank filtrate in drinking water wells. Water Science and Technology, 11: 654-658. 
Verplanck, P.L., Antweiler, R.C., Nordstrom, D.K., Taylor, H.E., 2001. Standard reference water samples for rare earth element determinations. Applied Geochemistry, 16: 231-244.

Verplanck, P.L., McCleskey, R.B., Roth, D.A., 2003. Inorganic water chemistry of the Boulder Creek Watershed, Colorado, during high-flow and low-flow conditions, 2000. In: S.F. Murphy et al. (eds.), Comprehensive Water Quality of the Boulder Creek Watershed, Colorado, During High-flow and Low-Flow Conditions, 2000. U.S. Geological Survey Water-Resources Investigation Reports 03-4045: 71-102.

Verplanck, P.L., Taylor, H.E., Nordstrom, D.K., Barber, L.B., 2005. Aqueous stability of gadolinium in surface waters receiv- ing sewage treatment plant effluent, Boulder Creek, Colorado. Environmental Science and Technology, 39: 6923-6929.

WIOŚ, 2000. Raport o stanie środowiska, cześć 1. Charakterystyka województwa - warunki klimatyczne. Wojewódzki Inspektorat Ochrony Środowiska w Kielcach.

Zhu, Y., Hattori, R., Rahmi, D., Itoh, S.O., Fujimori, E., Umemura, T., Haraguchi, H., 2005. Fractional distributions of trace metals in surface water of Lake Biwa as studied by ultrafiltration and ICP-MS. Bulletin of the Chemical Society of Japan, 78: 1970-1976. 